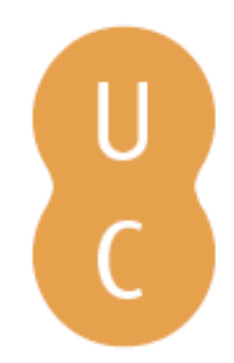

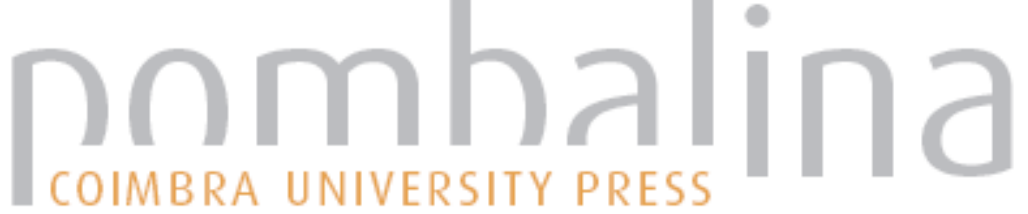

\section{Estados Unidos da América}

Autor(es): $\quad$ Sá, Tiago Moreira de; Joaquim, Emanuel Bernardes

Publicado por: Imprensa da Universidade de Coimbra

URL

persistente: URI:http://hdl.handle.net/10316.2/38490

DOI: $\quad$ DOI:978-989-26-0995-9 (PDF);

DOl:http://dx.doi.org/10.14195/978989260995-9_5

Accessed : $\quad$ 26-Apr-2023 11:19:36

A navegação consulta e descarregamento dos títulos inseridos nas Bibliotecas Digitais UC Digitalis, UC Pombalina e UC Impactum, pressupõem a aceitação plena e sem reservas dos Termos e Condições de Uso destas Bibliotecas Digitais, disponíveis em https://digitalis.uc.pt/pt-pt/termos.

Conforme exposto nos referidos Termos e Condições de Uso, o descarregamento de títulos de acesso restrito requer uma licença válida de autorização devendo o utilizador aceder ao(s) documento(s) a partir de um endereço de IP da instituição detentora da supramencionada licença.

Ao utilizador é apenas permitido o descarregamento para uso pessoal, pelo que o emprego do(s) título(s) descarregado(s) para outro fim, designadamente comercial, carece de autorização do respetivo autor ou editor da obra.

Na medida em que todas as obras da UC Digitalis se encontram protegidas pelo Código do Direito de Autor e Direitos Conexos e demais legislação aplicável, toda a cópia, parcial ou total, deste documento, nos casos em que é legalmente admitida, deverá conter ou fazer-se acompanhar por este aviso.

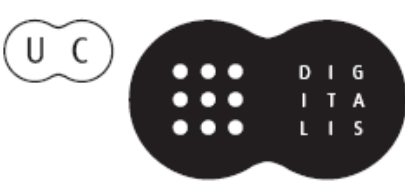




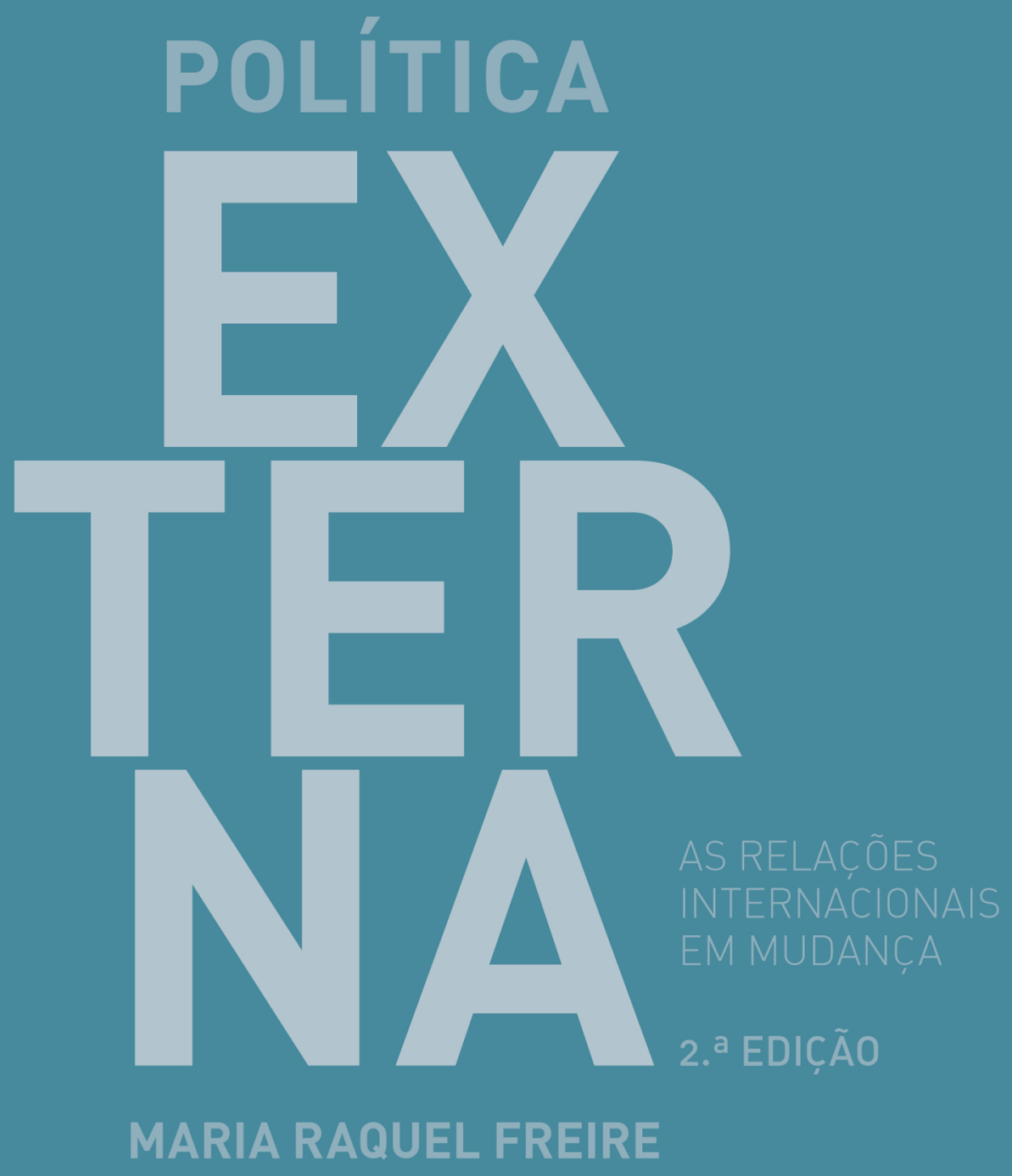

COORDENAÇÃO 


\section{CAPÍTULO 5 \\ ESTADOS UNIDOS DA AMÉRICA}

Tiago Moreira de Sá

e Emanuel Bernardes Joaquim

Este capítulo analisa a evolução da política externa norte-americana desde o fim da II Guerra Mundial até à atualidade, identificando a sua moldura teórica e as suas constantes e linhas de força. O argumento principal é que as orientações estratégicas das várias administrações foram enquadradas pelo Excepcionalismo americano, que se desenvolveu através da tensão entre realismo e liberalismo, coexistindo estes sem que se verificasse em qualquer momento um domínio absoluto de um sobre o outro. O texto está dividido em três partes. A primeira aborda as principais questões da teoria da política externa dos Estados Unidos da América (EUA). A segunda trata do período da Guerra Fria e do papel de Washington na construção da ordem internacional pós-1945. A terceira analisa o pós-colapso da União das Repúblicas Socialistas Soviéticas (URSS) e o momento unipolar da América.

\section{Realismo e Liberalismo como faces do Excepcionalismo na política externa americana}

Entre o fim da II Guerra Mundial e o princípio da Guerra Fria dá-se um fenómeno de coincidência entre a distribuição de po- 
der no sistema internacional e a produção teórica em Relações Internacionais, que corresponde à convergência da ascensão dos EUA em termos de poder com a sua afirmação na definição de uma disciplina ainda jovem. Desta vez, perante o colapso da Alemanha e do Japão, face ao desgaste do Império Britânico e da França e sob a sombra da expansão da URSS - com uma superioridade de poder convencional que se estendia até ao centro da Europa -, a retirada deixava de ser uma opção para o poder americano, em ascendente completo, do alto do seu monopólio atómico. Cabia-lhes assim o principal da ação na resistência contra o expansionismo soviético, mas isso significa que lhes cabia também a maior fatia do pensamento estratégico. Não é então de admirar que seja nos Estados Unidos que passe a ter lugar também a maior parte da produção teórica em Relações Internacionais, algo que se mantém até aos nossos dias com alterações menores do que seria de esperar. $\mathrm{O}$ domínio americano sobre a disciplina é tal que, já nos anos 1970, Stanley Hoffmann considera ser esta uma ciência social ou disciplina americana (Hoffmann, 1977).

A convergência entre a teoria e a realidade das Relações Internacionais tem, em especial no seu despontar, sequência lógica, regendo-se a primeira pelos acontecimentos da segunda. Tendo em conta o domínio dos EUA nos dois níveis, a consequência disto é que os primeiros desenvolvimentos teóricos têm como principais objetivos a descrição e compreensão das dinâmicas da realidade internacional que serve de contexto à nova situação do poder americano, assim como a procura de resolução dos seus problemas de política externa, então centrados na necessidade de enquadramento da estrutura internacional numa ideia de ordem e na iminência da ameaça soviética.

O contínuo debate em torno do papel da teoria na explicação e formação das Relações Internacionais, por um lado, e, de forma mais particular, os modelos que a mesma teoria procura aplicar na 
compreensão do poder americano e na sua ação nas suas várias fases históricas têm sido das linhas mais relevantes do desenvolvimento da disciplina. Contudo, é preciso que se tenha presente que, refletindo em boa parte a realidade, raramente a teoria nos seus contornos académicos se concretiza como plano seguido pelos decisores políticos. Se, como veremos, uma determinada ideia de realismo e liberalismo no caso americano marcam o percurso da política externa desde a II Guerra Mundial, essa ideia não é necessariamente a que criámos com as teorias, embora com elas tenha muito em comum. Na verdade, o realismo e o liberalismo, enquanto guias de política externa e já não enquanto modos de explicação da realidade, adquirem na prática contornos específicos, que devem muito à identidade e à experiência próprias dos Estados Unidos e da sua conceção de um Excepcionalismo americano. Do mesmo modo, nem sempre os dois surgem claramente separados, sendo mais correta a imagem de uma constante tensão em cada momento de definição da ação externa.

O termo Excepcionalismo é sem dúvida dos mais presentes no vocabulário da política externa americana, tendo vindo a acompanhá-la praticamente desde o início do seu processo de formação, para o qual, de uma maneira ou de outra, foi contribuindo. O conceito de Excepcionalismo Americano surge-nos associado a uma ideia de singularidade segundo a qual «a América é um caso único, diferente em aspetos cruciais da maioria dos outros países» (Lipset, 1997: 18-23), em variáveis como as políticas, sociológicas, religiosas, e geográficas que, por sua vez, conduzirão a um credo ideológico próprio impregnado na Constituição e no sistema político e caracterizado pela rutura com o passado. Trata-se de um conceito que começa, de um ponto de vista académico, por fazer a distinção da identidade americana num conjunto de variáveis internas, sendo um exemplo desta abordagem os estudos desenvolvidos a partir da questão das causas de não ter existido, de forma relevante, socia- 
lismo numa sociedade industrializada como a americana. Contudo, porque também ao nível da política externa se achou pertinente a identificação de elementos distintivos como estes, o conceito de Excepcionalismo estendeu-se para a vertente internacional da política americana, onde se tornou palavra essencial concorde-se ou não com as suas premissas.

E, se a existência ou não de um verdadeiro Excepcionalismo está longe de obter um acordo absoluto, o próprio conceito nasce de uma tensão entre duas dimensões que terão sustentado a sua criação. Arthur Schlesinger considera que as duas correspondem, respetivamente, a uma tradição e a uma contratradição, sendo a tradição aquela que olha para o Excepcionalismo como uma experiência - a experiência excecional americana -, sustentada em elementos concretos, e a contratradição a que o transforma numa ideologia, que encontra razões ulteriores para o sucesso da experiência americana, sob a forma de um Destino nacional messiânico (Schlesinger, 1977: 512). A experiência encontra expoente nos vários momentos fundadores, tendo como referência as reflexões dos Founding Fathers em torno da fragilidade da natureza humana e de uma relação com as experiências políticas republicanas. Esta última era a que fazia com que olhassem com reverência e temor para a que consideravam o seu único precedente, ou seja, a república romana, mas também para casos mais recentes, como os da Península Itálica na Idade Média e no Renascimento. Já a fragilidade da natureza humana, ligada a este registo histórico geralmente desfavorável às repúblicas, fez com que assentassem a nova experiência constitucional americana num espírito cético, consciente do seu caráter inédito e, sobretudo, da improbabilidade do seu sucesso, ainda para mais tendo em conta o contexto histórico específico em que se inseria. Este ceticismo associado à consciência da finitude e mesmo fragilidade das experiências políticas, a que acrescia a religiosidade escatológica calvinista, não impediu os fundadores de avançarem com a experiência como ver- 
dadeiro teste contra a história, o que lhe atribuía um caráter cético ou realista, mas não pessimista (Schlesinger, 1977: 512).

A abordagem a que Schlesinger chama de experiência americana é facilmente identificável com a tradição realista de uma maneira geral. Ainda que esta seja suscetível de grande diversidade, na sua versão clássica encontramos um conjunto de elementos comuns à generalidade das abordagens. Desde logo, em primeiro lugar, uma visão conservadora cética, se não mesmo pessimista, da natureza humana, marcada pela busca pelo poder e pela sobrevivência. Em segundo lugar, e ainda ligado ao primeiro princípio, a ideia de que o conflito é uma possibilidade constante, uma vez que decorre naturalmente da condição humana de eterna busca pelo poder e pela sobrevivência, num contexto de anarquia, que se define pela inexistência de um equivalente internacional ao Estado, que se imponha, como este internamente, sobre as várias unidades do sistema com um monopólio da violência física legítima. Em terceiro lugar, a centralidade do Estado como principal ator internacional, que, por sua vez, é visto de forma unitária, regendo a sua ação por pressupostos de racionalidade, representado pela figura do Estadista. Finalmente, a definição da política internacional como luta pelo poder, também esta decorrente das características intrínsecas da natureza humana (Morgenthau, 1992; Waltz, 1979). Esta perspetiva não só marcava a rutura com as conceções utopistas ou idealistas do período entre guerras, trocando o otimismo pelo ceticismo, como, ao fazê-lo, correspondia ao sentimento da fase inicial da Guerra Fria, de advento de uma bipolaridade nuclear, de competição militar férrea e de desfecho imperscrutável, tal como era incorporada pela luta pelo poder entre as duas superpotências, em que o que estava em causa, em última instância, era a própria sobrevivência. Mais especificamente, criará as bases para o desenvolvimento do que passa a ser considerado necessário: a contenção do expansionismo soviético (Knutsen, 1997: 216-220, 223-226). Por sua vez, a versão neorrealista de Kenneth 
Waltz introduz alterações relevantes, mas sem nunca fugir por completo a estes princípios. Assim, onde o Realismo Clássico vê natureza humana, propensão natural dos Estados ao conflito e busca pelo poder, o Neorrealismo vê dinâmicas estruturais assentes em três princípios ordenadores: o princípio da anarquia, conducente a uma lógica de autoajuda na ação internacional dos Estados; a não diferenciação funcional das unidades da estrutura internacional, cuja função corresponde à obtenção de segurança e, em última instância, da sobrevivência, verdadeira medida do interesse dos Estados; e a distribuição de poder e adjacente tendência à formação de equilíbrios de poder. A somar a tudo isto, o pai do Neorrealismo defendia ainda a ideia de que a estrutura bipolar, inédita até à Guerra Fria, pela sua incrível estabilidade, para a qual contribuía a existência de mútua dissuasão nuclear, estava para ficar (Waltz, 1979).

Quanto à contratradição nasce precisamente do sucesso da tradição. A experiência, contra todas as adversidades, resistira às primeiras décadas e impusera a democracia, no dizer de Tocqueville, como condição dos novos cidadãos americanos. Da improbabilidade do projeto, passou-se a concluir um destino providencial, que fazia do povo americano um motor da história, o povo eleito imediato perante Deus, a nova Israel (Schlesinger, 1977: 516), ou o novo Sto. Agostinho que, como dizia Bercovitch, conciliava os santos e o Estado como dois pilares de uma escatologia federal única (Schlesinger, 1977: 515). A sua missão liberal providencial seria estender a democracia, que já iluminava os americanos, aos outros povos, ainda presos às contingências de uma história de conflito. Foi esta ideia de missão que fez com que fosse o Presidente Wilson, na Europa de 1919, a considerar a América a única nação idealista do Mundo (Schlesinger, 1977: 517). Para Schlesinger, é também este espírito de cruzada que podemos encontrar no anticomunismo de John Foster Dulles ou de Ronald Reagan ou ainda na experiência traumática do Vietname, e, podemos acrescentar, no liberalismo intervencionista do pós-Guerra 
Fria. O idealismo da ideia de destino substituía-se assim à experiência como premissa da vida nacional, ao ponto de se dar ao luxo de, a partir de 1815, a seguir à guerra anglo-americana, retirar caprichosamente os Estados Unidos da própria História. Os americanos, rejeitando a História, pelo menos na medida em que não a possam mudar, passam a ser, deste modo, "an essentially historyless people» (Schlesinger, 1977: 518; Eisenstadt, 2007: 90, 93-95).

Há assim uma dialética que rapidamente se sobrepõe à destas tradição e contratradição, a da tensão entre realismo e liberalismo na política externa americana, correspondendo o realismo, com o ceticismo relativamente à natureza humana e ao papel da ideologia da sua versão clássica, à tradição, e o liberalismo, especialmente na sua face intervencionista ou ativista, à contratradição. No entanto, se o liberalismo, pela sua associação necessária a uma determinada matriz de valores, se relaciona mais claramente com a ideologia liberal americana, também o realismo assume no contexto do pensamento e ação da política externa dos EUA contornos específicos, que o colocam à parte de um denominado realismo continental, mais próximo da tradição teórica clássica. Assim, de acordo com Walter Russel Mead o realismo continental parte de três premissas essenciais que muito simplesmente não se aplicam na realidade americana e que justificam que se considere a sua abordagem realista distinta. A primeira tem que ver com o diferente foco depositado na economia. Se para os realistas continentais a política externa é assunto estritamente da esfera da política, para os americanos a economia é uma parte crucial na formação das ordens políticas internacionais. A segunda distinção está relacionada com uma questão de escala, separando a visão eurocêntrica dos continentais de uma visão do sistema global americana. Esta última resulta em grande parte da sua situação geográfica privilegiada, a salvo das consequências imediatas da lógica de uma balança de poder precária, inevitáveis no continente europeu, refletindo-se ainda na procura do estabele- 
cimento de um mercado global. E, finalmente, um último conjunto de considerações relativas à natureza do poder político, ao papel do Estado na sociedade e aos pontos fortes e fracos da democracia. Entre estas estão a ideia realista clássica da política externa dirigida por um único estadista que faz dos estados atores unitários e racionais, que se distingue da composição complexa do processo de tomada de decisão do sistema político americano. Também a visão negativa que têm os continentais da sua natureza democrática, tornando-a vulnerável às ambições imprudentes da opinião pública e aos valores abstratos que a sustentam, afirmando a existência de um "fosso moral" entre um ambiente interno lockeano, em que existe um consenso moral em torno de conceções gerais de vida boa, e um ambiente internacional hobbesiano, caracterizado pela diversidade de conceções morais e de interesses que competem e lutam entre si, por oposição à perspetiva dos públicos democráticos, para os quais a esfera internacional é uma extensão da doméstica (Mead, 2002: 36-40, 44, 45, 48, 54).

O Excepcionalismo Americano constitui deste modo mais que simplesmente uma identidade distinta, embora esta só por si já não deva ser de desprezar, com as consequências que tem na ação dos Estados ou no modo como estes veem o seu posicionamento internacional. Para além disso, fornece ainda um dos enquadramentos essenciais para as tensões que definem as suas grandes linhas ao longo do tempo. Tal não impede que nem sempre seja entendido desta forma e, por esse motivo, ou desprezado ou elevado a uma categoria quase religiosa. Assim, se entre muitos realistas se tende a relacionar o Excepcionalismo com ideologia e, por conseguinte, a rejeitá-lo, há entre alguns liberais moderados quem pretenda que é chegada a hora de se adotar uma política externa liberal pós-excepcionalista (Ikenberry e Deudney, 2012). Por outro lado, num debate que é já mais o dos políticos que o dos teóricos, a crença na nação excecional é considerada um pré-requisito quase tão importante como a filiação 
na fé cristã para alguém com ambições mais cimeiras na cena política americana. Não sendo exatamente esta a conceção que deva constituir o Excepcionalismo enquanto conceito com utilidade teórica, também aqui fica demonstrada a centralidade que tem o termo nas várias dimensões do ethos americano.

\section{Criar ordem e conter o expansionismo soviético: \\ a política externa americana ao longo da Guerra Fria}

O final da II Guerra Mundial e o estabelecimento no pós-conflito de uma estrutura de distribuição de poder bipolar representa para os EUA um conjunto de ruturas históricas importantes, de entre as quais a que mais se destaca é o fim de um relativo isolamento da política das grandes potências, que à época se concentrava esmagadoramente na Europa. As circunstâncias do pós-guerra, mas acima de tudo a nova posição americana na estrutura de distribuição de poder dão início a um novo período, que se estende até aos nossos dias, de comprometimento com os assuntos centrais de definição do sistema internacional. A concretização desta posição dá-se a partir de então com a atribuição aos Estados Unidos de um papel de equilibradores, garantidores de segurança global, uma vez que é também nesta altura que se dá a globalização do sistema internacional com o seu alargamento aos países saídos das vagas descolonizadoras, e regional, através da projeção de poder nas principais regiões do sistema. Este papel será no pós-guerra mundial especialmente relevante na Europa, que permanece como principal palco de disputa das contendas internacionais durante a Guerra Fria, onde estão claramente estabelecidos os dois blocos político-militares em confronto e onde a perspetiva de um expansionismo soviético se revela como ameaça iminente. Contudo, ainda que o pós-1945 se marque pela rutura, esta não é total, permanecendo como enquadramento da definição da política 
externa das sucessivas administrações o tal Excepcionalismo que se vai desenvolvendo por intermédio da tensão entre realismo e liberalismo nas suas versões americanas. Como se disse anteriormente, em nenhum momento se verifica um domínio absoluto de um ou outro modo de ver a realidade internacional. Em todos os períodos históricos há elementos realistas e liberais, contribuindo ambos para o resultado final de um processo que se concretiza na ação externa do Governo dos EUA. Ainda assim, há momentos em que um ou outro acaba por se impor de alguma forma, isto é, períodos de tempo que se caracterizam por uma ação predominantemente de cariz realista ou de pendor mais liberal. O exemplo mais flagrante de um momento claramente realista é o da política externa desenvolvida pela dupla Nixon-Kissinger, desde logo pelo seu descomprometimento relativamente a crises ou conflitos envolvendo aliados que não ponham em causa os interesses americanos, mas também pela sua aproximação à China comunista e ao modo como passa a sustentar a sua política soviética sobretudo numa gestão de cálculos de poder. Por outro lado, a Administração Clinton é um bom exemplo de uma abordagem liberal internacionalista, com intervenções que definem o próprio intervencionismo liberal, como o caso da intervenção humanitária na Somália, ou a guerra na Bósnia, mas também com a sua promoção do comércio internacional, impulsionando e liderando acordos de comércio livre, ou com o investimento na consolidação e alargamento da ordem institucional liberal. Numa linha de fronteira entre as duas escolas teóricas, temos o momento neoconservador da Doutrina George W. Bush e da intervenção militar no Iraque de 2003, também designado de forma criativa de "wilsonianismo realista", visando espalhar a democracia pelo chamado "Grande Médio Oriente» (Fukuyama, 2006: 7-11). Apesar destas frequentes tensões, a regra geral é a de uma conciliação entre realismo e liberalismo, como demonstram as próprias conceções de criação de ordem, nos seus vários momentos, e de contenção do expansionismo soviético, 
visando a primeira a institucionalização dos valores liberais na arena internacional ao mesmo tempo que busca uma aceitação do poder americano que lhe permita a manutenção de uma situação mais favorável em termos de distribuição de poder, e a segunda a permanência de uma situação de equilíbrio de poder, manifestando-se ao mesmo tempo numa resistência ideológica contra o totalitarismo.

Mas o caráter de rutura da mudança na forma de se posicionar internacionalmente está bem espelhado na renitência inicial dos Estados Unidos em assumirem a realidade do seu novo poder e da sua entrada na política das grandes potências. Na verdade, já tinham antes experimentado um pouco desta política: em finais do século XIX, na sua participação na Guerra dos Boxers, assumindo ainda assim uma posição distinta da das outras potências que procuravam dividir a China entre si, pretendendo antes que esta se mantivesse como nação independente, garantida a 'porta-aberta' ao comércio na região; em 1898, na Guerra Hispano-Americana, reafirmando a sua prevalência no Hemisfério Ocidental - o das Américas -, contra qualquer intruso europeu, tal como estipulava a sua já antiga Doutrina Monroe; e durante a primeira metade do século XX, com a mediação dos acordos de paz da Guerra Russo-Japonesa, logo em 1905, com a participação nas duas guerras mundiais e com o impulsionamento da Sociedade das Nações e da Organização das Nações Unidas após estes conflitos. Contudo, mesmo no envolvimento nestes acontecimentos é visível a busca de um afastamento sempre que possível, e, quando tal não se verifique, de uma abordagem que procura distinguir-se da lógica das relações de poder tradicionais europeias. A entrada nas guerras mundiais dá-se em ambos os casos quando estas já se encontravam a decorrer e apenas após ataques ou ameaças diretos contra alvos americanos. Apesar de a Sociedade das Nações ser impulsionada pela Administração Wilson, correspondendo ela própria a uma tentativa enquadrada na perspetiva americana de relações internacionais, avessa aos módulos clássicos das relações 
de poder, a participação dos EUA enquanto Estado-membro acaba por ser vetada pelo seu próprio Senado, onde os isolacionistas foram voz dominante até Pearl Harbor. Já no decorrer da II Guerra Mundial, o Presidente Franklin D. Roosevelt planeava para o que viesse depois uma divisão do poder internacional num esquema de "quatro polícias» do mundo - os Estados Unidos, a China, a União Soviética e o Império Britânico -, cada um responsável por uma região e relativamente harmoniosos entre si, numa visão que não encontrava paralelos no passado (Lafeber, 2006: 14-15).

Todavia, no fim da guerra, a situação a que faria face o seu sucessor era outra, como já ia sendo possível intuir nas várias conferências entre os aliados na luta contra as potências do Eixo ainda durante o conflito. Quando, em 1947, em plena guerra civil na Grécia, ainda se esperava que fosse a Grã-Bretanha a arcar com as despesas da resistência contra os avanços do comunismo na Europa, a Administração Truman depara-se com uma realidade bem diferente. O Império Britânico era uma sombra do que fora no passado, e em breve deixaria de ser império, não tendo já sequer capacidade para continuar a financiar os esforços da monarquia grega para resistir contra os insurgentes comunistas. Do mesmo modo, também a França se encontrava devastada pela guerra, em que cedo tivera grande parte do seu território sob ocupação. Já a Alemanha e o Japão, os grandes derrotados, achavam-se arruinados e com o seu território ocupado pelas potências vencedoras, sendo que no caso da Alemanha se verificava ainda uma divisão que permaneceria por décadas. Quanto à China, voltava à guerra civil que viria a terminar (não oficialmente) em 1949, com a vitória comunista (White, 2006: 53-57; Leffler, 2010: 73-77).

No novo quadro de distribuição de poder restavam apenas duas grandes potências, as principais vencedoras da II Guerra Mundial: os Estados Unidos e a URSS. Os primeiros saíam da guerra, com o seu território praticamente intocado, com um número de baixas 
humanas muito inferior ao verificado nas outras potências beligerantes e, o que é mais importante, com uma economia que acabou por beneficiar do esforço de guerra e do aumento da sua capacidade produtiva, fomentado pela procura europeia em resultado da destruição do seu tecido produtivo, passando a representar $50 \%$ da riqueza mundial. A isto acrescia a nova capacidade militar conseguida durante a guerra, sendo aqui de destacar o monopólio temporário da bomba atómica, a arma que viria mudar o modo como a guerra passaria a ser calculada. Por outro lado, com o declínio das outras potências ocidentais e do Japão, cabia sobretudo aos Estados Unidos a responsabilidade pela proteção do mundo livre (ou não comunista) contra a ameaça do totalitarismo encabeçada pela União Soviética (Engerman, 2010: 31-34). Embora com contornos distintos do das guerras até aí existentes, a luta travar-se-ia sem tréguas, como disso iam sendo demonstrativos a formação do bloco soviético, a guerra civil na Grécia, a crise do bloqueio de Berlim, entre 1948 e 1949, a aquisição da bomba atómica pela União Soviética em 1949 e a decorrente corrida armamentista, ou ainda a guerra da Coreia, que começava em 1950 (Gaddis, 1997: 1-26).

A inserção internacional dos Estados Unidos no pós-guerra e ao longo da Guerra Fria desenvolve-se assim em duas dimensões, que procuram responder a duas questões essenciais: a do enquadramento normativo do seu novo poder internacional; a da defesa do status quo e consequente necessidade de contenção do expansionismo soviético. A primeira dimensão, que procura responder à primeira das questões levantadas, será a da criação e manutenção de ordem internacional (Waltz, 1993: 45-46; Ikenberry, 2000; Ikenberry, 2006). A segunda corresponde a tudo o que diz respeito à elaboração da arquitetura de defesa da Guerra Fria, das alianças e bases militares espalhadas pelo globo, ao progresso e investimento em tecnologias de armamento, no contexto de uma competição feroz que tem por base, em primeiro lugar, a dissuasão nuclear assente numa lógica de 
mútua destruição assegurada e, em segundo, a política de contenção propriamente dita (Holloway, 2010: 384-389).

A necessidade de um enquadramento normativo para a aplicação do seu poder representava a visão missionária idealista já anteriormente posta em prática por Woodrow Wilson, que pretendia ultrapassar as contingências que criavam as condições para o conflito com base nos valores liberais impressos na identidade americana (White, 2006: 63-65; Bacevich, 2006: 387-391). Esse enquadramento normativo é dado precisamente pela criação e manutenção de ordem no sistema internacional. De facto, podemos considerar a existência de três momentos ordenadores internacionais por parte dos Estados Unidos: o primeiro é o da criação da Sociedade das Nações, que se verifica incompleto, pois, criando ordem, os americanos não participam na sua manutenção, sendo que a própria organização fracassa no cumprimento do principal objetivo da sua criação: evitar uma II Guerra Mundial; o segundo é o do pós-II Guerra Mundial, que corresponde já à criação de um conjunto mais abrangente de normas e instituições, que se desenvolvem em diferentes níveis e áreas e que são acompanhadas pela manutenção da ordem através da garantia do poder americano; o terceiro momento dá-se após o final da Guerra Fria e corresponde, com uma curta exceção, à consolidação, aprofundamento e alargamento da ordem criada a seguir ao fim da II Guerra Mundial e que entretanto já se tinha vindo a desenvolver progressivamente (Maier, 2006: 20-21).

A ordem internacional que é criada pelos EUA depois do fim da II Guerra Mundial abrange várias áreas, o que, desde logo é bem visível na diversidade das agências e órgãos que compõem a ONU, fundada em São Francisco, a 24 de outubro de 1945. Contudo, destaca-se nesta organização o seu caráter político, incorporado pelo Conselho de Segurança. De certa forma, ele acaba por ser uma adaptação, com menos alcance, da fórmula dos "quatro polícias» pretendida por Roosevelt, tendo não quatro, mas cinco membros 
permanentes, os Estados Unidos, a União Soviética (e depois Rússia), a República da China (que seria substituída pela República Popular da China), a Grã-Bretanha e a França. Por muito que se critique a sua incapacidade para agir decisivamente quando mais seria necessário, algo que decorre do seu sistema de voto que dá poder de veto aos membros permanentes, o que acaba por paralisar frequentemente o seu funcionamento, em última instância a sua história é de sucesso, sobretudo se comparada com a do seu antecessor do período entre-guerras, como atesta a sua duração. É verdade que, ao longo da Guerra Fria, a paralisia de que sofria permitiu uma única intervenção sob os seus auspícios, durante a Guerra da Coreia, e mesmo essa aproveitando-se uma ausência temporária da União Soviética, em protesto contra o facto de não ser a liderança comunista chinesa a ocupar o assento no Conselho. Mas este acabou por se revelar um importante veículo para o diálogo entre grandes potências, especialmente relevante no contexto de um conflito longo e caracterizado por um clima de constante tensão. A Assembleia Geral, pelo seu lado, acaba por ser o órgão mais democrático, onde têm assento, com voto de igual valor, todas as Nações Unidas, que vão aumentando de número e de diversidade à medida que as antigas colónias europeias vão adquirindo a sua independência. No seu conjunto, a ONU é um projeto que transporta consigo a marca americana, que busca, assim, moldar normativamente o sistema internacional em torno de uma ideia de ordem democrática e aberta, de que é exemplo a Declaração Universal dos Direitos do Homem, à qual se juntarão os direitos económicos e sociais como cedência aos Estados socialistas (Maier, 2006).

Num nível inferior de abertura, encontra-se o projeto de ordenamento nas áreas da economia e das finanças, conhecido como sistema de Bretton Woods. O nível de abertura é relativamente inferior não porque o sistema fosse formalmente fechado, mas porque se mostrava incompatível com as posições defendidas por Estados re- 
gidos por ideologias assumidamente anticapitalistas. O principal fim dos países reunidos em Bretton Woods, no New Hampshire, em julho de 1944, foi o de desenvolver uma economia de mercado submetida a um conjunto de regulações e mecanismos compensatórios, como o Fundo Monetário Internacional ou o Banco Internacional para Reconstrução e Desenvolvimento, que mais tarde seria integrado no Banco Mundial. Porém, o que mais é de destacar é o facto de, pela primeira vez, se chegar à criação de uma ordem monetária negociada entre os Estados, que colocava no seu centro o dólar americano associado ao padrão ouro, algo que se manteria até 1971, altura em que o governo americano abandona unilateralmente o padrão ouro. Esta medida seria seguida por outros Estados, muitos dos quais passam a usar o dólar como moeda de reserva, o que aumentaria a sua centralidade no sistema (Ikenberry, 2006: 368-373; Hitchcock, 2010: 166-171).

Finalmente, num nível ainda mais específico, temos o enquadramento institucional das várias alianças de segurança e defesa impulsionadas pelos Estados Unidos em várias regiões do mundo, de entre as quais é mais uma vez de realçar a que se desenvolve no palco europeu, ou seja, a Organização do Tratado do Atlântico Norte (OTAN), fundada em 1949. Embora o seu propósito imediato não fosse a criação de ordem mundial, mas sim a contenção do expansionismo soviético na Europa, num contexto de ameaça iminente, acaba por ser, a par do Plano Marshall, um impulsionador das iniciativas ordenadoras no continente europeu, centro do sistema internacional. Visando a união de esforços como resposta à ameaça de um inimigo específico, acabaria por resultar num longo período de paz, inédito entre as potências da Europa, assim como num processo de contínua integração política e económica. Tendo no seu núcleo o compromisso dos seus membros com os valores democráticos, é este nível de ordenamento que corresponde, por excelência, à criação de uma ordem liberal (Maier, 2006: 26-41; Trachtenberg, 1999: 95-145) 
É também neste nível que se estabelece a ligação entre as duas grandes dimensões da política externa americana ao longo da Guerra Fria, sendo que a política de contenção constitui-se como o seu elemento estratégico mais distintivo. A política de contenção, nas suas várias manifestações, surge como resposta estratégica à ameaça do que era percecionado como um altamente provável expansionismo soviético. De forma mais ou menos assertiva, a posição de contenção da expansão da URSS permanece ao longo de todo o conflito bipolar, visando precisamente contê-la até que esta se transformasse pelas contradições do seu próprio sistema, na linha do que se retirou dos contributos de George F. Kennan logo no despoletar daquele período (Kennan, 1947).

A contenção é simultaneamente um produto do realismo e do liberalismo. No primeiro caso, acreditava-se que, ainda que impenetráveis pela via da lógica da razão, os soviéticos seriam sensíveis à lógica da força, o que levou Kennan a recomendar que eles fossem contidos através de «um constante contrapoder» exercido pelos Estados Unidos em "qualquer parte do mundo" onde ameaçassem a estabilidade e a paz (Kennan, 1947: 862). No segundo caso, pensava-se que a culpa da conflitualidade estava nas raízes do próprio sistema russo-Soviético, o que transformou a contenção numa empresa moral, ou seja, o combate do bem - liberalismo - contra o mal - comunismo -, que acabaria com a vitória do primeiro (Kissinger, 2007: 453-456). Um exemplo disso foi o Plano Marshall, não só pelos seus contornos, mas por um dos seus propósitos: pôr fim à situação de fragilidade económica dos Estados da Europa ocidental, que os expunha aos riscos da ascensão do comunismo junto das suas populações. A própria esperança da conversão ideológica da União Soviética mais não era que o reflexo do velho sonho americano de uma paz alcançada pela conversão do adversário (Hitchcock, 2010).

A contenção permanecerá então, de forma mais ou menos evidente, como a posição americana ao longo da Guerra Fria, estabelecendo- 
-se como padrão de toda esta época: ação soviética contraposta por reação americana. A resposta dos EUA, sempre obedecendo ao objetivo primacial de manutenção do equilíbrio global de poderes, variou ainda assim em torno de dois estilos distintos de contenção, que alternaram entre si, sendo um de resposta simétrica e outro de assimétrica. O primeiro pressupõe a reação a ameaças ao equilíbrio de poderes no local, tempo e em níveis equivalentes aos da provocação original; o segundo consiste numa resposta que envolve a mudança do local ou da natureza da provocação para terreno mais favorável, tendo em vista evidenciar as fraquezas do adversário, recuperando capacidade de iniciativa. Um exemplo de contenção assimétrica é o da que parte da estratégia original sugerida por George Kennan, e em parte seguida pela Doutrina Truman, a partir da qual se desenvolve o Plano Marshall, que visava a manutenção dos grandes centros de poder industrial-militar fora da esfera de influência soviética. Outro exemplo é o da inversão da administração Eisenhower a seguir à Guerra da Coreia, usando a ameaça de uso de armas nucleares como dissuasor e forma de manter a incerteza no adversário (McMahon, 2010: 293-297). Os dois casos mais óbvios de contenção simétrica são as Guerras da Coreia, entre 1950 e 1953, e do Vietname, que conta com a participação mais ativa dos Estados Unidos entre 1965 e 1973, e, em termos estratégicos, o documento do Conselho de Segurança Nacional NSC 68, da autoria de Paul Nitze (Fakiolas, 1998).

A contenção assimétrica de Nixon-Kissinger é mais peculiar, consistindo acima de tudo num descomprometimento americano, que implicava menor assistência na defesa dos aliados dos EUA pelo mundo. Subsidiariamente, contemplava uma estratégia que, através de pressões e incentivos, procurava a moderação da União Soviética, de forma a que esta aceitasse as "regras do jogo", processo que ficou conhecido pelo conceito assimétrico por excelência de linkage. A Administração Carter viria a adotar uma abordagem assimétrica semelhante, mais por necessidade que por vontade, devido aos 
constrangimentos da dependência energética e da inflação (Gaddis, 1982: 345 e segs.).

De facto, a partir dos anos 1960, e ainda mais à medida que a participação na Guerra do Vietname se vai prolongando, comprometendo os Estados Unidos com perdas crescentes, sem que haja resultados visíveis ou interesses nacionais claramente envolvidos, mas também na sequência da tensão da crise dos mísseis de Cuba, em 1962, que colocou o mundo à beira do apocalipse nuclear, e da contínua escalada armamentista, uma variante distinta de contenção assimétrica vai tomando forma, acabando por ter o seu auge ao longo dos anos 1970. O nome pelo qual ficaria conhecida esta abordagem da contenção, também ela suscetível de variações e diferentes compreensões, seria détente. Mais que uma simples forma de contenção, veio a constituir-se como um conceito multiforme, que incluía as estratégias dos vários países que procederam a políticas de détente, mas também o ambiente das relações que se estabelecem entre esses países (nomeadamente, entre Este e Oeste), caracterizado por um relaxamento das tensões existentes, como a própria definição do termo o indica (Garthoff, 1985: 25).

Não há apenas uma détente, mas várias: entre a França e a URSS, entre a Alemanha Ocidental, os soviéticos e seus satélites na vizinhança daquela, conhecida também pelo nome alemão de ostpolitik, numa referência clara à sua viragem a Leste, tendo em vista o reconhecimento das fronteiras do pós-guerra de uma maneira que deixasse em aberto a possibilidade do melhoramento das relações com a Alemanha de Leste, ou ainda entre os países da OTAN e os do Pacto de Varsóvia, com especial destaque para a União Soviética, cujo momento alto viriam a ser os acordos de Helsínquia, em 1975. Contudo, a détente que aqui nos interessa é aquela que envolve os Estados Unidos, podendo esta ser observada sob várias perspetivas: a das relações entre a América e União Soviética, a da visão americana sobre tais relações e respetivas estratégias e a da visão 
soviética. Há ainda a considerar uma outra possibilidade de détente, neste caso entre os EUA e a República Popular da China (Bell, 1977). Esta, porém, não poderá ser vista independentemente das relações russo-americanas, devendo ser integrada na perspetiva de uma estratégia de Washington de política triangular que pretendia exercer pressão sobre os soviéticos no sentido de obter maiores cedências destes servindo-se da tensão crescente nas relações entre Moscovo e Pequim. Uma tal perspetiva enquadra-se perfeitamente na ideia de détente como estratégia americana, em que esta é vista como uma forma de gerir o poder do adversário (Bell, 1977: 1), ou mais especificamente na estratégia elaborada por Nixon e Kissinger, que se distinguia de um objetivo em si: era um meio para atingir um ou mais fins, e não um fim em si mesma (Garthoff, 1985: 29).

A estratégia de détente da dupla Nixon-Kissinger inseria-se claramente na tradição realista. Ela pretendia reduzir o risco de uma confrontação entre as duas superpotências nucleares, ao mesmo tempo que continha a expansão do poder soviético, num sistema internacional que se acreditava estar em transição da bipolaridade para a multipolaridade (ou multipolaridade pentagonal, nas palavras de Kissinger) e numa altura em que os EUA estavam em retraimento estratégico depois da aventura do Vietname e a URSS tinha alcançado a paridade estratégica relativa. (Kissinger, 2007: 622-623). Adicionalmente, ela assentaria no conceito linkage, isto é, na associação de incentivos à moderação do poder de Moscovo e de punições sempre que esta não manifestasse moderação em áreas consideradas cruciais, tudo isto independentemente das diferenças ideológicas e de natureza dos sistemas políticos. A détente desdobrava-se como forma de gestão do poder/comportamento do adversário (Garthoff, 1985: 30-31).

A détente viria a entrar em declínio ainda durante as Administrações Nixon e Ford, caindo definitivamente em 1979, durante o tempo de Carter, com a invasão soviética do Afeganistão, mas em resultado 
de um mais vasto conjunto de fatores. O primeiro tem que ver com a fragmentação do sistema político americano, que se verifica desde logo no interior do próprio executivo e ainda mais nas suas relações com o Congresso. Este obstáculo tornar-se-ia ainda mais evidente com a resignação de Nixon, levando à paralisação da Casa Branca, com a descredibilização do termo détente durante as eleições de 1976, ou ainda com a divisão no seio do próprio executivo de Carter entre uma posição de maior assertividade face à União Soviética de Zbigniew Brzezinski, então Conselheiro de Segurança Nacional, o desejo de maior cooperação de Cyrus Vance, Secretário de Estado, perante a indecisão inicial ou desejo de compromisso entre as duas possibilidades do Presidente (Garthoff, 1985: 33-35). O segundo fator está relacionado com a perceção interna da parte de algumas elites políticas, sobretudo à direita, de détente como entente, ou com o entendimento errado ou simplesmente diverso do conceito de linkage, que levou a que muitos procurassem associar a cooperação com a URSS a cedências que envolviam a mudança do seu sistema interno na polémica questão dos direitos humanos, particularmente no respeitante à questão dos dissidentes políticos ou da emigração de judeus russos. Se este começara por ser um intento de elementos do Congresso, como o Senador Henry Jackson e a famosa Emenda Jackson-Vanik, viria a ser integrado por Carter numa ambiciosa política de direitos humanos, ainda que o mesmo acabasse depois, ele próprio, por simplesmente abandonar esta perspetiva (Gaddis, 1981: 84-85). Em terceiro lugar, os entendimentos (americano e soviético) distintos do conceito de détente viriam a colidir quando os EUA começam a falhar na sua capacidade de fornecer incentivos à mudança do comportamento da URSS noutras áreas do globo, mas também porque a conceção de Moscovo não pressupunha linkage com a competição no terceiro mundo, o que levou a que novas situações de crise ou tensão, como os casos de Angola, do Corno de África, da invasão do Vietname do Sul pelo Vietname do Norte, 
ou do Afeganistão, viessem atrapalhar a cooperação entre as duas potências (Gaddis, 1981: 84; Westad, 2007: 158-330).

\section{Os Estados Unidos e o fim da Guerra Fria}

As Administrações Reagan e Bush seriam as últimas antes do fim da Guerra Fria, tendo sido durante o mandato de George H. Bush que os acontecimentos definitivos de desmantelamento da sua estrutura se viriam a dar. Do muito que se tem escrito sobre as causas e responsabilidades pelo fim deste período que se estendera por mais de 40 anos há a destacar três grandes escolas de pensamento: a das causas norte-americanas, a das causas soviéticas e a das causas dos satélites da Europa de Leste.

A primeira escola busca resposta nas causas americanas. Numa das suas versões, designada de "triunfalista", a Guerra Fria acabou com a vitória dos Estados Unidos sobre a URSS. De acordo com esta corrente, a Administração Reagan provocou o fim do conflito bipolar ao acelerar o colapso soviético através da adoção de uma política externa ofensiva destinada a explorar as fragilidades de Moscovo, supostamente conhecidas em Washington, levando a cabo ações como um programa de rearmamento maciço, a Iniciativa de Defesa Estratégica (SDI) e a aposta numa retórica mais contundente e neo-wilsoniana. Para os "triunfalistas", foi a combinação desta política ambiciosa, que conjugava poder militar e ideologia com a incapacidade do Kremlin de acompanhar o ritmo dos gastos em defesa e a competição tecnológica, que levou à implosão da União Soviética. Revertendo a visão "triunfalista», uma outra corrente sustenta que, ao invés de terem aproximado o fim da Guerra Fria, as políticas mais duras de Reagan levaram antes ao seu adiamento, ao reforçarem os setores ultra em Moscovo, retirando apoio interno a Gorbachev para seguir as suas reformas (Fischer, 2010: 267-269). 
A segunda grande escola desloca a atenção para a União Soviética, considerando que não foi Washington que venceu o conflito bipolar, mas sim Moscovo que o perdeu ao implodir, sobretudo por três motivos: as políticas de Gorbachev, o expansionismo excessivo no Terceiro Mundo e o colapso da sua economia (Judt, 2010: 671$-674)$.

A terceira escola de pensamento centra-se nas causas localizadas nos satélites soviéticos da Europa de Leste. Segundo esta perspetiva, as revoluções de 1989 tiveram um papel relevante na implosão da URSS (Stokes, 1993).

Por muito que possa não ter sido a causa principal do fim da Guerra Fria, a ação da Administração Reagan foi bastante importante para caracterizar a última década do conflito. No entanto, o conjunto dos seus mandatos deve ser dividido em duas fases distintas: o primeiro, entre 1981 e 1984, a que podemos chamar de "o momento liberal", em que adota uma política de confronto ideológico e geopolítico; o segundo, no resto da sua presidência, o "momento realista", em que procura uma diminuição da tensão na relação entre as superpotências, tendo mesmo negociado os mais ambiciosos programas de redução de armamentos nucleares (Mann, 2011)

De facto, o contexto em que Ronald Reagan ascende à presidência dos Estados Unidos é marcado por uma perceção pública de declínio americano, associada à convicção de superioridade estratégica soviética e à ideia de que os comunistas estavam a vencer a competição bipolar no Terceiro Mundo, a que podemos somar a ideia de fraqueza deixada pela Administração Carter. Assim, perante a imagem de uma séria ameaça soviética, Reagan adota uma política com três frentes, mas com um objetivo central: recuperar a superioridade estratégica norte-americana. Para isso, apresentou o maior orçamento de defesa de sempre em tempo de paz, procurou desestabilizar a URSS através de uma "guerra económica" 
e reforçou significativamente o apoio às forças nacionais que se opunham a Moscovo em várias partes do mundo (Garthoff, 1994: 29). A acompanhar esta maior assertividade ao nível da competição estratégica, enceta uma guerra retórica e ideológica, que deixa vincado o caráter irreconciliável das diferenças entre a democracia liberal e o comunismo, numa abordagem que resulta como uma versão simplificada do pensamento de Woodrow Wilson, enraizada na utopia americana e traduzida na forma de uma luta entre o bem e o mal (Kissinger, 2007: 675).

Mas Reagan estava longe de defender que o conflito era a única alternativa. Pelo contrário, acreditava que seria capaz de converter o adversário, levando-o a reconhecer que a sua filosofia política estava errada e, uma vez ultrapassada a rivalidade ideológica, a disputa pelo poder entre as superpotências acabaria. A retórica do presidente americano baseava-se sobretudo na esperança de uma progressiva democratização da União Soviética, o que levaria a uma melhoria relevante no relacionamento Leste-Oeste. No fundo, tratava-se de uma política de contenção retórica, em que o elemento de mudança de regime do adversário passa a ser declarado (Hass, 2005: 196).

Todavia, no início de 1984 dá-se uma inversão desta abordagem liberal, quando, num discurso sobre as relações americano-soviéticas inaugura uma nova política denominada não por acaso de realistic engagement, baseada na cooperação e no entendimento entre os dois países. Os seus grandes objetivos eram, em primeiro lugar, reduzir o enorme volume de armamentos estratégicos e, em segundo lugar, terminar com os muitos conflitos regionais a ter lugar um pouco por todo o mundo, visando ambos a redução da tensão resultante das posturas de confrontação das duas superpotências (Fischer, 2010: 273). Uma das principais razões para esta mudança significativa da posição americana foi o facto de as políticas seguidas durante o primeiro mandato não terem verdadeiramente obtido grande êxito. $\mathrm{Na}$ verdade, a sua retórica e atuação duras reforçaram os setores 
mais radicais na União Soviética, criaram tensões dentro da Aliança Atlântica e contribuíram para o fortalecimento de alguns movimentos antiamericanos na Europa Ocidental (Maier, 2005). Outra das razões que contribuíram para esta nova postura foi a mudança na liderança da União Soviética, com a ascensão de Gorbachev (Patman, 2006). Embora esta só se tenha dado já depois de 1984, criou as condições para que a aproximação fosse mútua, desde logo imprimindo a mudança num conjunto de políticas reformistas, como a Perestroika e a Glasnost, e depois pela abertura demonstrada na negociação em várias áreas, das quais se destaca claramente a redução de armamentos estratégicos, concretizada nos acordos START (Fischer, 2010: 278).

Contudo, a Guerra Fria viria a terminar já durante o mandato de George H. Bush, cuja ação, traduzida no apoio a Gorbachev e no empenho em manter um bom relacionamento entre as superpotências, resistindo à tentação de fomentar a queda da URSS, foi importante para que a transição se tivesse dado sem incidentes mais graves. De facto, coube a este presidente a gestão da fase final do conflito bipolar e da transição para o pós-União Soviética, tendo de lidar com problemas tão difíceis e perigosos quanto a queda do muro de Berlim e a subsequente reunificação alemã, as ondas de choque da implosão soviética nas suas antigas repúblicas e satélites da Europa de Leste, o que fazer com os arsenais nucleares espalhados por mais do que um país. Não tendo sido necessariamente da política externa americana que resultaram as principais causas para que a Guerra Fria tivesse terminado na altura em que terminou e nos contornos verificados, esta foi sem dúvida fundamental no pós-1991. Este, por sua vez, concretizar-se-ia numa mudança da estrutura de poder e de legitimação do papel ordenador internacional equivalente ao do pós-II Guerra Mundial, voltando a levantar as questões sobre o que fazer com o novo poder americano e com a nova ordem internacional (Painter e Blanton, 2002: 484). 


\section{O Pós-Guerra Fria: unipolaridade e ordem}

O fim da Guerra Fria representa um conjunto de mudanças profundas na realidade internacional, sendo a maior a que se dá na estrutura de distribuição de poder, em que a bipolaridade é substituída pela unipolaridade, caracterizada pela existência de uma única superpotência, ou uma hiperpotência como lhe chamaria um membro do governo francês: os Estados Unidos (Krauthammer, 2006). Uma tal concentração de poder é inédita na época moderna e ainda mais desde que existe um sistema de Estados com uma estrutura de abrangência global. No entanto, a importância deste facto vai para lá da simples distribuição de poder, uma vez que a inexistência de poderes contrabalanceadores, em conjunto com a derrota definitiva do comunismo, passa a significar que deixa de haver alternativas sérias ao projeto de criação de uma ordem liberal. Embora as proclamações de fim da História caiam necessariamente no exagero, não era totalmente descabida à época a ideia de triunfo liberal (Fukuyama, 1999).

Tal não significa ainda assim que acabem as questões que necessariamente teriam de surgir face a uma tal concentração de poder, sendo estas colocadas, em primeiro lugar, pelos Estados renitentes em aderir aos valores liberais (Monteiro, 2011/2012: 26-33), em segundo, por aqueles que cientes das prescrições realistas não confiam em qualquer concentração excessiva de poder seja qual for o seu caráter, em terceiro, pelos teóricos que debatem sobre a durabilidade da unipolaridade ou os seus contornos de ordem internacional.

O debate em torno da durabilidade da unipolaridade é importante, pois pressupõe a existência de diferentes perceções sobre o caráter do poder americano e as suas implicações na estabilidade da estrutura internacional. Para autores como Kenneth Waltz ou Christopher Layne a existência de um sistema unipolar é necessariamente transitória, uma vez que há uma tendência estrutural natural 
para se contrabalançar qualquer concentração de poder tida como excessiva. Assim, Waltz recomendava em 1993 que, em vez de se prepararem para a gestão de um período longo de unipolaridade, os Estados Unidos deviam ir-se preparando para uma situação a que não estavam habituados, como seja, a partilha de poder no contexto de um sistema multipolar emergente. Já Layne avisava que não era seguro que o caráter do poder americano se concretizasse em autocontenção, uma vez que um grande poder nem sempre é acompanhado de grande responsabilidade (Waltz, 1993; Layne, 2006).

Wohlforth contrapõe este argumento nas suas duas vertentes: a da durabilidade e a do caráter do poder americano. Contra o que defendiam Waltz e Layne, Wohlforth considerava que a unipolaridade teria longa duração e era pacífica. Em primeiro lugar, porque os seus níveis de concentração de poder eram tais que não havia forma de qualquer coligação de Estados chegar sequer perto de se lhe sobrepor, devendo as potências de segunda ordem, quando não aliar-se mesmo à superpotência, pelo menos, buscar a acomodação à estrutura por si dominada. Em segundo lugar, porque a estrutura unipolar é significado de estabilidade, já que simplifica os cálculos de poder a fazer, que se passam a resumir praticamente ao alinhamento com os Estados Unidos, o que contribui também para a diminuição da possibilidade de conflitos de larga escala. Em terceiro lugar, devido ao caráter democrático liberal do poder americano, que o levava a considerar os Estados Unidos uma potência hegemónica benevolente (Wohlforth, 1999: 5-41).

Ikenberry desenvolve um argumento que vai de encontro à ideia de poder benevolente de Wohlforth, sob a forma de um conceito de ordem constitucional liberal. De facto, para este autor, uma das principais razões na base da criação da ordem internacional do pós-II Guerra Mundial é a autocontenção do poder americano. A ordem funciona assim como um instrumento de autocontenção estratégica, procurando os Estados Unidos na aceitação pacífica da 
sua hegemonia conseguir garantir que esta se prolongue de forma estável. As normas e instituições internacionais funcionam como os tais constrangimentos necessários à concentração de poder, sendo que, através destas, e tirando ainda proveito do caráter aberto do sistema político americano, podem os outros Estados procurar influenciar a forma como esse poder é exercido (Ikenberry, 2000; Ikenberry, 2006).

Precisamente, de acordo com Ikenberry, é este mais uma vez um dos principais propósitos subjacentes ao que considerámos o terceiro momento ordenador dos Estados Unidos, que corresponde à consolidação, alargamento e aprofundamento da ordem internacional liberal. A consolidação dá-se pela confirmação de muitas das normas e instituições anteriormente criadas, muitas das quais com prazo de validade previsto para o fim da Guerra Fria. Ao nível da ONU, temos a primeira intervenção no Iraque, em 1991, que se dá sob a égide do Conselho de Segurança (a primeira em que isto acontece desde a guerra da Coreia), uma coligação que abrangeria um grande número de Estados, incluindo a União Soviética. $\mathrm{Na}$ área económica, é criada a Organização Mundial de Comércio, que substitui o GATT, e à qual viriam a aderir a Rússia e a China. Também ainda ao nível do comércio internacional, na sequência do aprofundamento da integração europeia, multiplicam-se os acordos de comércio livre, como a NAFTA, liderada pelos Estados Unidos. Mas é sem dúvida a OTAN a que melhor espelha esta ideia de consolidação, bem como, ao mesmo tempo, de alargamento. Tendo sido criada com o intuito de conter a expansão soviética, não só sobrevive, adaptando-se, como tem as suas primeiras intervenções já depois de desmantelada a União Soviética. A adaptação passa pela tomada de novos papéis, aos quais é comum a manutenção da estabilidade europeia, seja através do seu alargamento aos países da Europa de Leste, que contribui para que os seus processos de transição se deem de forma relativamente estável, seja pela intervenção na resolução de conflitos na Europa, 
como nos casos da Bósnia e do Kosovo, ou ainda na manutenção dos equilíbrios de poder, através da contenção da Alemanha pela sua participação na organização, e a garantia da segurança do continente, que se joga também na sua periferia, em missões do Índico à costa ocidental africana. Expoente do multilateralismo ocidental, não deixa de ser absolutamente crucial à OTAN o poder americano, principal responsável pela garantia material e organizacional da sua existência, o que faz dela um seu instrumento de política externa, que visa a tal estabilidade europeia e da sua periferia (Ikenberry, 2000; Ikenberry, 2006).

Tudo isto encontra concretização na política externa das várias administrações americanas que se seguem ao fim da Guerra Fria, que corresponde, no fundo, à resposta que cada uma procurou dar à questão sobre o que fazer com o esmagador poder americano. Aqui, podemos delinear a existência de três momentos, associados a cada uma das administrações. O primeiro esboço de resposta surgiu a 1 de outubro de 1990, sob a forma de um discurso de George H. Bush na ONU, em que este anuncia o que chamou de nova ordem mundial, cujo conteúdo se inscrevia no quadro de uma estratégia conservadora de manutenção do status quo internacional, ou seja, de preferência pela ação multilateral, de valorização das organizações internacionais - incluindo a subordinação da ação externa dos Estados Unidos ao Conselho de Segurança da ONU - e de respeito pelo direito internacional (Bush e Scowcroft, 1998: 299). Este é o momento realista, que põe em destaque o caráter conservador da estratégia americana, que assumia o interesse nacional de acomodação do seu poder de uma forma que desincentivasse a ascensão de potenciais desafiadores à sua manutenção.

Esta orientação estratégica conservadora foi seguida pela Administração Clinton, ainda que com a introdução de algumas variantes importantes, que fazem com que esta se constitua como o momento liberal. Desde logo, uma visão pós-soberanista das relações 
internacionais, refletida nas intervenções humanitárias na Somália, na Bósnia e no Kosovo. Depois, uma nova doutrina, designada de "Alargamento", definida por Anthony Lake, o Conselheiro de Segurança Nacional, como «o alargamento da comunidade mundial das democracias de mercado" e que se traduziu em concreto na expansão do modelo democrático liberal à escala global e no referido alargamento da OTAN, bem como da União Europeia com o apoio de Washington (Lake, 1993). Ainda a não exclusão da adoção de uma política de mudança de regime no Iraque, ainda que ela não tenha chegado a ser posta em prática, apesar da operação militar Desert Fox em 1998 (Chollet e Goldgeier, 2008).

Os ataques às Torres Gémeas e ao Pentágono, a 11 de setembro de 2001, marcaram uma profunda mudança na política externa norte-americana, com a adoção de uma orientação estratégica revisionista, que ficou conhecida como o momento neo-conservador (Leffler, 2006: 29-32), para alguns autores confundível com o liberalismo de Woodrow Wilson, ao ponto de ter sido também chamado de wilsonianismo com esteroides (Fukuyama, 2006: 43). A nova política de alteração da ordem internacional, mais conhecida por Doutrina Bush, introduz um conjunto de conceitos em larga medida contrários à visão de relações internacionais dos Estados Unidos pelo menos desde 1945: o unilateralismo, que substitui a preferência pelo multilateralismo; a guerra preventiva, que substituiu o conceito tradicional de contenção; as coligações variáveis, em substituição das coligações institucionais ou permanentes; a subalternização da ONU e do direito internacional à liberdade de ação dos Estados Unidos; a mudança de regime pela força, com o seu extremo de democratização do grande Médio Oriente, a começar pelo Iraque (Bush, 2002). Todavia, a partir de 2006 dar-se-ia um regresso à orientação conservadora, ainda que com uma variante de retraimento estratégico, traduzida, por exemplo, no início do processo de saída do Iraque (Cox, 2006). 
De facto, o prolongamento da guerra em duas frentes, no Afeganistão e no Iraque, de forma desgastante e sem resultados muito visíveis, em simultâneo com a ascensão de potências como a Índia ou, sobretudo, a China, e a crise económico-financeira de 2008 contribuíram para a intensificação do debate em torno do declínio relativo do poder americano, de resto recorrente desde o pós-II Guerra Mundial.

Uma escola de pensamento, que inclui autores como Fareed Zakaria e Michael Mandelbaum, entre outros, defende que estamos a assistir à transição da unipolaridade para a multipolaridade em resultado do declínio relativo dos Estados Unidos (e do Ocidente em geral) e da "ascensão do resto». Embora existam diferenças significativas entre os académicos inscritos nesta perspetiva relativamente às causas, ao grau e ao significado do declínio norte-americano, a tese dominante é a de que a perda de poder do país é relativa - isto é, tem de ser entendida em comparação com os seus mais diretos competidores -, e tem sobretudo uma natureza económica, com destaque para os seguintes indicadores: a evolução do PIB, a percentagem na produção industrial mundial, o peso da dívida e o custo dos direitos sociais (Zakaria, 2011; Mandelbaum, 2010).

Uma escola de pensamento completamente diferente é a de Robert Kagan, que contesta a tese do fim da unipolaridade e mesmo a do declínio de poder dos EUA, baseando-se para isso sobretudo no que chama de indicadores básicos para medir as mudanças no poder relativo de um Estado, tais como: o tamanho e a influência da sua economia relativamente a outras potências; a magnitude do poder militar quando comparada com o de potenciais adversários; e o grau de influência política no sistema internacional. Para Kagan, o problema dos que defendem o declínio do poder dos Estados Unidos resulta, simultaneamente, de apenas se considerar o período de tempo que vai da crise financeira de 2008 à atualidade, ou seja, apenas meia dúzia de anos, e de os indicadores básicos para medir 
as mudanças de poder não só não confirmarem esta tese, como revelarem mesmo o contrário, isto é, que as bases fundamentais do poder norte-americano não se alteraram de forma fundamental desde o colapso do Lehman Brothers. Segundo Kagan é esta a conclusão a extrair quando analisamos os indicadores económicos, que se mantiveram estáveis ao longo das últimas quatro décadas. Os Estados Unidos são hoje a maior economia do mundo, com uma percentagem da riqueza global igual à de 1969; o seu PIB é de 16.7 trillion USD (enquanto, por exemplo o da China é de 13.3 trillion USD; o PIB per capita é de 52.8 mil dólares, ocupando o 14 . $^{\circ}$ lugar a nível mundial (Kagan, 2012).

Inscrevendo-se na primeira escola, chamada de declinista, a Administração Obama intensificou o retraimento estratégico iniciado já no final do último mandato de George W. Bush, adotando uma Grande Estratégia de Offshore Balancing traduzida numa redução significativa do perímetro de envolvimento norte-americano no exterior, agora limitado às três regiões estrategicamente vitais para Washington, como sejam a Europa, o Nordeste Asiático e o Golfo Pérsico, bem como no abandono da preferência pela colocação do seu poder militar Inshore (Obama, 2010; Indyk, Lieberthal, O'Hanlon, 2012). Para além disso, tem procurado fazer face à nova realidade da ascensão da China e da crescente importância relativa do continente asiático (Layne, 2012) com uma estratégica denominada de rebalancing (Clinton, 2011) que estabelece a região da Ásia-Pacífico como prioritária e de grande relevância para os interesses americanos, procurando o desenvolvimento de uma arquitetura de contenção, assente no reforço das alianças bilaterais e multilaterais e na deslocação de forças para aquele perímetro regional, ao mesmo tempo que busca um maior envolvimento da China nas regras e instituições que alicerçam a ordem internacional. Trata-se, no seu conjunto, de uma política externa que se pode incluir no realismo defensivo, que busca uma manutenção do status quo ao mesmo tempo que se 
vai preparando para a possibilidade de alterações na estrutura de distribuição de poder, numa altura em que esta parece manifestar mais alguma fluidez.

\section{Considerações finais}

A grande questão que se coloca na atualidade é a de saber qual o impacto da transição de poder e da diversidade no sistema internacional na política externa dos EUA e na sua função de garante das normas, leis e instituições da ordem mundial numa perspetiva de tempo longo.

Desde final dos anos 2000, assistimos a um conjunto de fenómenos económicos e políticos que originaram a ascensão de novas potências - a China e a Índia, no continente asiático, e o Brasil, no continente sul-americano - e o declínio de poder relativo do bloco ocidental. Apesar de estas novas potências terem acordos bilaterais com vários estados-membros da União Europeia e com os Estados Unidos, tem-se assistido à sua crescente relutância em aceitarem a hegemonia ocidental, com destaque para algumas decisões de política externa americana na última década.

Este fenómeno tem particular incidência no campo económico, havendo exemplo claros de insatisfação relativamente ao modelo ocidental. O "capitalismo de estado" chinês é cada vez mais frequentemente apontado por países em vias de desenvolvimento como um modelo a seguir. Da mesma forma, a China tem criado relações comerciais privilegiadas com países africanos e latino-americanos com vista a preencher as lacunas do sistema comercial americano e europeu. O Brasil e a Índia não têm perdido oportunidades de expressar o seu descontentamento nas várias rondas da OMC. Muito recentemente, os BRICS criaram o seu próprio Branco para o Desenvolvimento, que, apesar de segundo os seus fundadores 
não ter como fim substituir o Fundo Monetário Internacional, está a desenvolver um sistema de empréstimos com regras diferentes deste.

Apesar do debate interno acerca da alegada abdicação do excepcionalismo americano por parte da administração Obama, os Estados Unidos têm respondido a estes desafios de um modo que mantém a combinação do Realismo e do Liberalismo como faces desse $e x$ cepcionalismo, fazendo-o sobretudo de dois modos distintos, mas complementares: incentivando a integração das potências emergentes nas instituições da ordem mundial, sobretudo através dos G20 e da OMC; recriando a ordem ocidental, com destaque para a criação de acordos bilaterais de comércio livre como o que está em negociação com a União Europeia - o TTIP. Em ambos os casos o objetivo último é a manutenção da ordem liberal construída pelos norte-americanos a seguir à II Guerra Mundial e expandida no pós-1991.

\begin{tabular}{|l|}
\hline Quadro 1. \\
\hline Questões para análise \\
\hline $\begin{array}{l}\text { De que forma as leituras teóricas das Relações Internacionais informam a análise da política } \\
\text { externa dos EUA? }\end{array}$ \\
\hline $\begin{array}{l}\text { Caraterize o excepcionalismo norte-americano e o seu significado no desenvolvimento das } \\
\text { principais linhas de política externa. }\end{array}$ \\
\hline $\begin{array}{l}\text { Explique em que consistiu e como foi implementada a política de containment dos EUA } \\
\text { durante a Guerra Fria. }\end{array}$ \\
\hline $\begin{array}{l}\text { Analise as principais diferenças e similitudes em matéria de política externa entre as várias } \\
\text { Administrações Americanas nas duas últimas décadas. }\end{array}$ \\
\hline
\end{tabular}

\begin{tabular}{|l|}
\hline Quadro 2. \\
\hline Fontes na internet \\
\hline Casa Branca, www.whitehouse.gov \\
\hline Departamento de Estado, www.state.gov \\
\hline Departamento de Defesa, www.defenselink.mil \\
\hline The National Security Archive, http://www.gwu.edu/ nsarchiv \\
\hline Council on Foreign Relations, http://www.cfr.org/ \\
\hline
\end{tabular}




\begin{tabular}{|c|}
\hline Quadro 3. \\
\hline Leituras recomendadas \\
\hline Cox, Michael; Stokes, Doug (2012) US Foreign Policy. Oxford: Oxford University Press. \\
\hline $\begin{array}{l}\text { Melvyn P. Leffler e Odd Arne Westad (2010) The Cambridge History of the Cold War. } 3 \text { vols, } \\
\text { Cambridge: Cambridge University Press. }\end{array}$ \\
\hline $\begin{array}{l}\text { Gaddis, John Lewis (1997) We Now Know: Rethinking Cold War History. Nova Iorque: Oxford } \\
\text { University Press. }\end{array}$ \\
\hline $\begin{array}{l}\text { Hass, Mark L., (2005) The Ideological Origins of Great Power Politics, 1789-1989. Ithaca: Cornell } \\
\text { University Press. }\end{array}$ \\
\hline $\begin{array}{l}\text { Ikenberry, G. John (2006) Liberal Order and Imperial Ambition: Essays on American Power } \\
\text { and International Order. Londres: Polity Press. }\end{array}$ \\
\hline
\end{tabular}

\section{Bibliografia}

Bacevich, Andrew J. (2006) "New Rome, New Jerusalem», in Cox, Michael (org), Twentieth Century International Relations, vol. III, Sage Library of International Relations.

Bell, Coral (1977) The Diplomacy of Détente. The Kissinger Era. Londres: M. Robertson.

Bush, George; Scowcroft, Brent (1998) A World Transformed. Nova Iorque: Vintage Books.

Bush, George W. (2002) National Security Strategy 2002. [http://georgewbush-whitehouse.archives.gov/nsc/nss/2002/] (consultado a 10 de março de 2015).

Chollet, Derek; Goldgeier James (2008) America between the Wars: From 11/9 to 9/11. Nova Iorque: Public Affairs.

Clinton, Hillary (2011) "America's Pacific Century», Foreign Policy, novembro.

Cox, Michael; Stokes, Doug (2012) US Foreign Policy. Oxford: Oxford University Press.

Cox, Michael (2006) "The Empire's Back in Town: Or America's Imperial Temptation - Again", in Cox, Michael (org), Twentieth Century International Relations, vol. III, Sage Library of International Relations.

Eisenstadt, Samuel N. (2007) Múltiplas Modernidades. Ensaios. Lisboa: Livros Horizonte.

Engerman, David C. (2010). "Ideology and the origins of the Cold War,1917-1962", in Leffler, Melvyn P. e Westad, Odd Arne (org), The Cambridge History of the Cold War, vol. 1. Cambridge: Cambridge University Press.

Fakiolas, Efstathios T. (1998) "Kennan's Long Telegram and NSC-68: A Comparative Analysis", East European Quarterly, 31(4), 415-433.

Fischer, Beth A. (2010) "US Foreign Policy under Reagan and Bush", in Leffler, Melvyn P. e Westad, Odd Arne (org), The Cambridge History of the Cold War, vol. 3. Cambridge: Cambridge University Press. 
Fukuyama, Francis (2006) America at the Crossroads: Democracy, Power, and the Neoconservative Legacy. New Haven: Yale University Press.

Fukuyama, Francis (1999) O Fim da História e o Último Homem. Lisboa: Gradiva.

Gaddis, John Lewis (1997) We Now Know: Rethinking Cold War History. Nova Iorque: Oxford University Press.

Gaddis, John Lewis (1982) Strategies of Containment: A Critical Appraisal of American National Security Policy. Nova Iorque: Oxford University Press.

Gaddis, John Lewis (1981) "Containment: Its Past and Future», International Security, 5(4), 74-102.

Garthoff, Raymond (1994) The Great Transition: American-Soviet Relations and the End of the Cold War. Washington D.C.: Brookings Institution.

Garthoff, Raymond (1985) Détente and Confrontation: American-Soviet Relations from Nixon to Reagan. Washington: Brookings Institution.

Hass, Mark L. (2005) The Ideological Origins of Great Power Politics, 1789-1989. Ithaca: Cornell University Press.

Hitchcock, William I. (2010) "The Marshall Plan and the creation of the West", in Leffler, Melvyn P. e Westad, Odd Arne (org), The Cambridge History of the Cold War, vol. 1. Cambridge: Cambridge University Press.

Hoffmann, Stanley (1977) An American Social Science: International Relations in Daedalus, 106(3), 41-60.

Holloway, David (2010) «Nuclear weapons and the escalation of the Cold War, 1945-1962", in Leffler, Melvyn P. e Westad, Odd Arne (org), The Cambridge History of the Cold War, vol. 1. Cambridge: Cambridge University Press.

Ikenberry, G. John; Deudney, Daniel (2012) «Democratic Internationalism: An American Grand Strategy for a Post-exceptionalist Era», Council on Foreign Relations, International Institutions and Global Governance Program.

Ikenberry, G. John (2006) Liberal Order and Imperial Ambition: Essays on American Power and International Order. Londres: Polity Press.

Ikenberry, G. John (2006) "American Power and the Empire of Capitalist Democracy", in Cox, Michael (org), Twentieth Century International Relations, vol. III, Sage Library of International Relations.

Ikenberry, G. John (2000) After Victory: Institutions, Strategic Restraint, and the Rebuilding of Order after Major Wars. Princeton: Princeton University Press.

Judt, Tony (2010) Pós-Guerra: História da Europa desde 1945. Lisboa: Edições 70.

Indyk, Martin S.; Lieberthal, Kenneth G.; O'Hanlon, Michael E. (2012) Bending History: Barack Obama's Foreign Policy. Washington D.C.: Brookings Institution Press.

Kennan, George F (1947) "The Sources of Soviet Conduct», Foreign Affairs, Council on Foreign Affairs, julho.

Kagan, Robert (2012) The World America Made. Nova Iorque: Alfred A. Knopf.

Kissinger, Henry (2007) Diplomacia. $3^{\text {a }}$ ed. Lisboa: Gradiva.

Knutsen, Torbjorn (1997) A History of International Relations Theory: An Introduction. Manchester: Manchester University Press. 
Krauthammer, Charles (2006) "The Unipolar Moment", in Cox, Michael (org), Twentieth Century International Relations, vol. III, Sage Library of International Relations.

Lafeber, Walter (2006) «The 'Lion in the Path': The U.S. Emergence as a World Power» in Cox, Michael (org), Twentieth Century International Relations, vol. III, Sage Library of International Relations.

Lake, Anthony (1993) From Containment to Enlargement. [https://www.mtholyoke. edu/acad/intrel/lakedoc.html] (consultado a 10 de março de 2015).

Layne, Christopher (2012) "The Global Power Shift from West to East", The National Interest, maio-junho, 119.

Layne, Christopher (2006) «The Unipolar Illusion Revisited: The Coming End of the United States' Unipolar Moment", International Security, 32(2), 7-41.

Leffler, Melvyn P. (2010) "The emergence of an American grand strategy, 1945-1952", in Leffler, Melvyn P. e Westad, Odd Arne (org), The Cambridge History of the Cold War, vol. 1. Cambridge: Cambridge University Press.

Leffler, Melvyn P. (2006) "9/11 and the Past and Future of American Foreign Policy», in Cox, Michael (org), Twentieth Century International Relations, vol. VIII, Sage Library of International Relations.

Lipset, Seymour Martin (1997) American Exceptionalism: A Double-Edged Sword. Nova Iorque: W. W. Norton \& Company.

McMahon, Robert J. (2010) «US national security policy from Eisenhower to Kennedy", in Leffler, Melvyn P. e Westad, Odd Arne (org), The Cambridge History of the Cold War, vol. 1. Cambridge: Cambridge University Press.

Maier, Charles S. (2006) "The Making of 'Pax Americana': Formative Moments of United States Ascendancy», in Cox, Michael (org), Twentieth Century International Relations, vol. III, Sage Library of International Relations.

Maier, Charles (2005) "Hegemony and Autonomy Within the Western Alliance», in Leffler, Melvyn P. e Painter, David S. (org), Origins of the Cold War: an International History. $2^{\text {a }}$ ed. London: Routledge.

Mandelbaum, Michael (2010) The Frugal Superpower. America's Glogal Leadership in a Cash-Strapped Era. Nova Iorque: Public Affairs.

Mann, James (2011) The Rebellion of Ronald Reagan: A History of the End of the Cold War. Nova Iorque: Penguin Books.

Mead, Walter Russell (2002) Special Providence, American Foreign Policy and How It Changed The World. Nova Iorque: Routledge.

Monteiro, Nuno P. (2011/12) «Unrest Assured: Why Unipolarity Is Not Peaceful», International Security, 36(3), 9-40.

Morgenthau, Hans (1992) Politics among Nations, The Struggle for Power and Peace. McGraw Hill, $6^{\text {th }}$ ed. revised by Kenneth Thompson.

Obama, Barack (2010) National Security Strategy 2010. [http://www.whitehouse. gov/sites/default/files/rss_viewer/national_security_strategy.pdf] (consultado a 10 de março de 2015).

Painter, David S.; Blanton, Thomas S. (2002) "The End of the Cold War", in Agnew, Jean-Christophe e Rosenzweig, Roy (org), A Companion to Post-1945 America. Malden: Blackwell Publishers. 
Patman, Robert G. (2006) «Reagan, Gorbachev and the Emergence of 'New Political Thinking'" in Cox, Michael (org), Twentieth Century International Relations, vol. II, Sage Library of International Relations.

Schlesinger, Arthur (1977) «Experiment or Destiny?», The American Historical Review, 82(3), 505-522.

Stokes, Gale (1993) The Walls Came Tumbling Down. The Collapse of Communism in Eastern Europe. Oxford: Oxford University Press.

Trachtenberg, Marc (1999) A Constructed Peace. The Making of European Settlement 1945-1963. Princeton: Princeton University Press.

Walt, Stephen M (2011) «Is IR still 'an American social science'?», Foreign Policy, 2011. [http://foreignpolicy.com/2011/06/06/is-ir-still-an-american-social-science/] (consultado a 10 de março de 2015).

Waltz, Kenneth N. (1993) "The Emerging Structure of International Politics", International Security, 18(2), 44-79.

Waltz, Kenneth (1979) Theory of International Politics. Nova Iorque: McGraw-Hill.

Westad, Odd Arne (2007) The Global Cold War, Third World Interventions and the Making of Our Time. Cambridge: Cambridge University Press.

White, Donald W. (2006) "The Nature of World Power in American History: An Evaluation at the End of World War II", in Cox, Michael (org), Twentieth Century International Relations, vol. III, Sage Library of International Relations.

Wohlforth, William C. (1999) "The Stability of a Unipolar World", International Security, 24(1), 5-41.

Zakaria, Fareed (2011) The Post-American World. 2. ${ }^{a}$ ed. Nova Iorque: W.W. Norton \& Company. 